\title{
C-33 A NEW SUB-THRUST PLAY FOR HYDROCARBON EXPLORATION IN CENTRAL ALBANIA - SEISMIC AND STRUCTURAL INTERPRETATION
}

\author{
ERIC DEVILLE' ${ }^{1}$ and ALBAN COLLAKU² \\ Institut Français du Pétrole \\ ${ }^{2}$ Coparex International, 135 Rue J.J. Rousseau, \\ 92138 Issy-les-Moulineaux, France
}

The stratigraphy of the Ionian and Kruja Albanian zones can be subdivided in four sedimentary sequences: 1. Triassic evaporites, 2. Ionian Triassic to Eocene basin and Kruja platform carbonates, 3. Oligocene to Burdigalian flysch, and 4. Tortonian to Pliocene molassic sediments deposited in the foreland basin.

Triassic evaporites are composed mainly of halite, gypsum and anhydrite with rare interbedded dolomite and shales. They constitutes the major decollement level.

Ionian Triassic - Eocene basin carbonates outcrop in the south-western part of Albania and Greece. They are characterised by great thickness and facies changes of the Upper Triassic to Cretaceous series indicating the occurrence of tilted blocks and confined sub-basins. Slumps and carbonate turbidites are frequent in the Upper Cretaceous-Paleocene. Excellent source rocks are known either in Upper Triassic or Liassic bituminous dolomites, and in the Toarcian posidonia schist. The Ionian carbonates are the main oil producing system in Albania. About 280 million bbls of oil and $560 \mathrm{Bcf}$ of associated gas initial recoverable reserves have been discovered.

Kruja series, represented by Upper Cretaceous to Eocene shallow water platform carbonates constitute two surface trends in central Albania. Seismic and drilling data indicate that these trends correspond to a duplex structures detached from their pre-Cretaceous substratum. Numerous oil seeps and shows are known in Kruja carbonates.

Oligocene - Burdigalian flysch starts with a marly transition facies on top of the Ionian and Kruja Eocene carbonates. It constitutes a very good seal.

Tortonian - Pliocene molasse outcrops in Pre-Adriatic depression and is represented by clay and sandstone. These sediments contain a large amounts of dispersed organic matter, the source for biogenic or mixed biogenic / thermogenic gas. They have sourced 6 gas fields with initial recoverable reserves about $110 \mathrm{Bcf}$.

The first deformations affected the Kruja platform and Ionian basin in Burdigalian. These events resulted in the tectonic accretion of these units in the Albanian allochthonous, in the creation of a new flexural basin further west (Pre-Adriatic depression), as well as in the development of Neogene piggyback basins on top of the already accreted Kruja and Ionian thrust. These thrust structures have been affected by a strong post-Burdigalian and ante-Serravalian erosion and are covered by the molassic Tortonian deposits. The outermost deformation occurred during the Pliocene, resulting in a regional backthrusting of the Neogene infill of the Pre-Adriatic depression onto the bordering Kruja zone and development of passive-roof duplexes at depth. This tectonic evolution is supported by the seismic data.

Following the interpretation of new seismic lines a deep seismic reflector (below 2.0 stwt) identified in the central Albanian foreland fold-and-thrust belt directly below the Kruja carbonate sheets is interpreted as a new sub-thrust carbonate play. It has not been 
explored yet by any well. According to our present interpretation, this lower sub-thrust unit consists of Ionian carbonates covered by flysch and represents a new perspective for hydrocarbon exploration in central Albania. From a structural point of view, it is comparable with the prolific Val D'Agri sub-thrust plays in the southern Apennines where four major fields have been discovered recently with a total of recoverable reserves estimated at one billion bbl of oil equivalent.

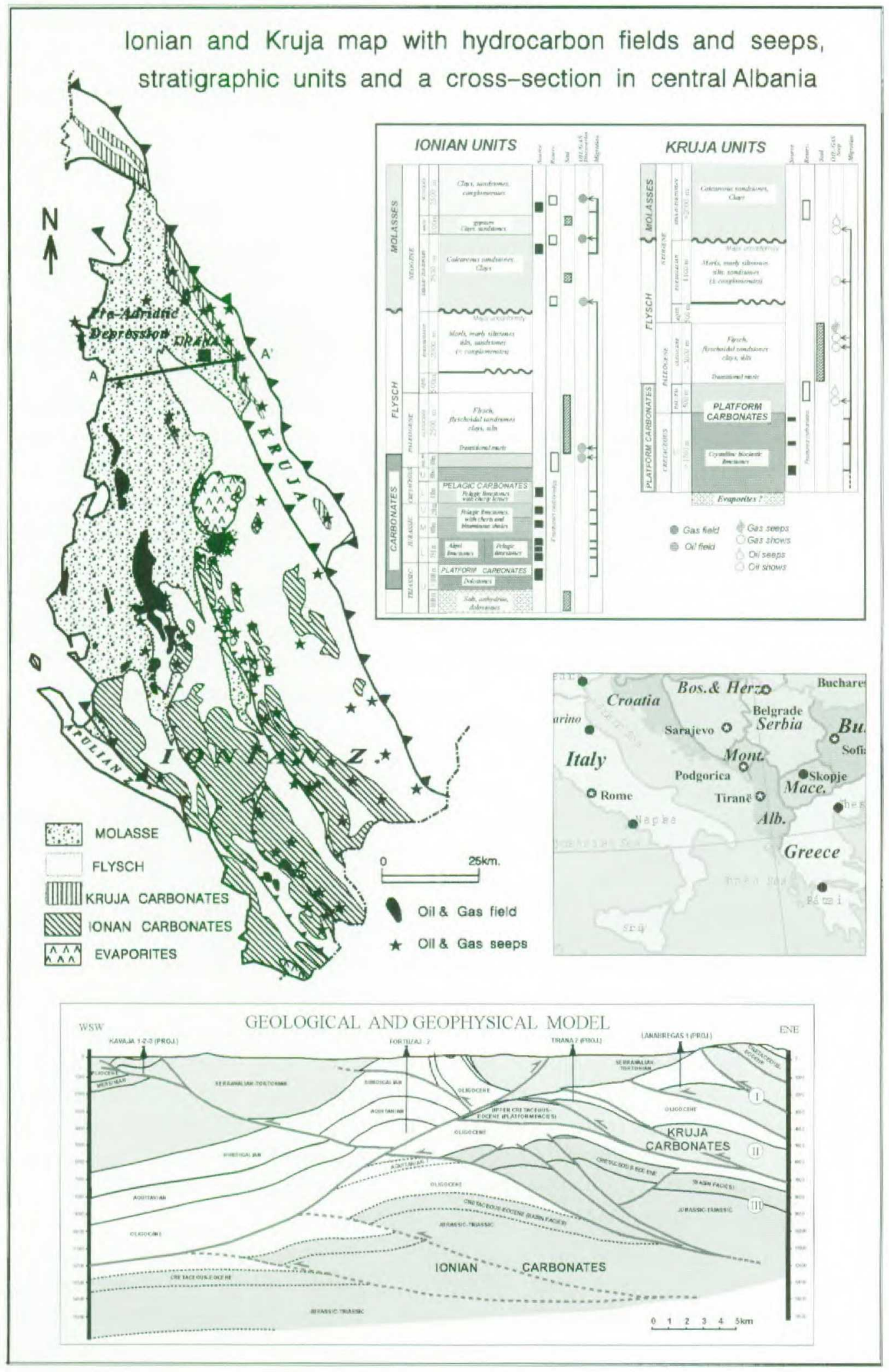

